UDC 616-056.7-07

\title{
Identification and characterization of six new mutations in $G L B 1$ gene in Ukrainian patients with GM1 gangliosidosis and Morquio B disease
}

\author{
N. Y. Mytsyk ${ }^{1,2}$, N. G. Gorovenko² \\ ${ }^{1}$ National Children's Specialized Hospital Okhmatdyt, Ministry of Health of Ukraine \\ 28/1, Chornovola Str., Kyiv, Ukraine, 01135 \\ 2 State Institute of Genetic and Regenerative Medicine, NAMS of Ukraine \\ 67, Vyshhorodska Str., Kyiv, Ukraine, 04114 \\ mytcyk_nat@ukr.net
}

\begin{abstract}
GM1-gangliosidosis (MIM\# 230500) and mucopolysaccharidosis IVB (Morquio B, MIM\# 230500) are autosomal-recessive diseases, which belong to the group of lysosomal storage disorders and are caused by changes in the structure of the same gene, GLB1. The mutations in GLB1 lead to deficiency in acid $\beta$-galactosidase, and, as a result, the accumulation of GM1-gangliosidosis and keratan sulphate in the patients' lysosomes. Aim. To analyze the spectrum of mutations in GLB1 in Ukrainian patients with GM1 gangliosidosis and Morquio B disease. Results. We analyzed GLB1 in 25 Ukrainian patients with the diagnosis of GM1-gangliosidosis and one patient with Morquio B disease; 52 alleles were analyzed. Seventeen types of pathogenic mutations were identified, including 11 missense replacements, three deletions, one insertion and two mutations in the splicing site. The missense mutation p.His $281 \mathrm{Tyr}(\mathrm{c} .841 \mathrm{C}>\mathrm{T})$ in exon 8 was found to be the most common, as it was found in 19 out of 52 mutant alleles $(36.5 \%)$ of all the examined patients. The study allowed to identify six new mutations, which had not been found in any databases or previously described in scientific literature, including three deletions (c.699delG, c.833delG, c.1203 1205delTTA), two missense replacements (p. Gly243Arg, p.Gly262Ala) and one mutation in the splicing site (IVS12+8T $>$ C). Conclusions. Our results can be used for a precise molecular diagnostics of patients with GM1-gangliosidosis and Morquio B disease and prenatal diagnostics in the high risk families.
\end{abstract}

Ke y w or d s: GM1-gangliosidosis, Morquio B disease, gene GLB1.

\section{Introduction}

GM1-gangliosidosis (MIM\# 230500) and mucopolysaccharidosis IVB (Morquio B, MIM\# 230500) are autosomal-recessive diseases, which belong to the group of lysosomal storage disorders and are caused by changes in the structure of the same geneGLB1 [1]. The mutations in gene GLB1 lead to the deficiency in acid $\beta$-galactosidase, and, as a result, the accumulation of GM1-gangliosidosis and keratan sulphate in the patients' lysosomes.

GM1-gangliosidosis is a clinically heterogeneous, neurodegenerative disease. The general incidence rate of this disease in the world is $1: 100,000$ 1:200,000 newborns [2, 3]. GM1-gangliosidosis may be divided into three clinical forms: type I (infantile form), type II (juvenile form), type III (adult form). In patients with the infantile form, the disease is manifested during their first six months of life with severe pathology of the central nervous system. The juvenile form is characterized by neurological changes and disorders in the locomotor system, which are manifested at the age from 7 months to 3 years. The adult form of the disease is manifested at the age from 3 to 30 years and is characterized by the disorders in the coordination of movements, dysto-

(C) 2016 N. Y. Mytsyk et al.; Published by the Institute of Molecular Biology and Genetics, NAS of Ukraine on behalf of Biopolymers and Cell.

This is an Open Access article distributed under the terms of the Creative Commons Attribution License (http://creativecommons.org/licenses/by/4.0/), which permits unrestricted reuse, distribution, and reproduction in any medium, provided the original work is properly cited 
nia, developmental language disorders, short stature and moderate changes in the skeleton.

Morquio $\mathrm{B}$ disease is referred to mucopolysaccharidosis type IV and is remarkable for multiple skeletal changes, short stature, corneal opacity, and disorder of the cardiac function [3]. The incidence of Morquio B disease in the world has a wide range from 1:75,000 newborns in the Northern Ireland [4] to 1:640,000 newborns in Western Australia [5]. In contrast to GM1-gangliosidosis, the patients with Morquio B disease do not have neurological symptoms. It is possible that the mutations, responsible for the deficiency in $\beta$-galactosidase, have different impact on the ability of the enzyme to split different substrates (GM1-ganglioside and keratan sulphate). However, recently the borders between GM1gangliosidosis and Morquio B disease have become less and less distinct, as some identified mutations in the gene GLB1 caused the intermediate phenotype with neurological symptoms and skeletal changes in the patients [1].

The gene GLB1 is mapped on chromosome 3 in the locus $3 \mathrm{p} 21.33$, is $62.5 \mathrm{~kb}$ long, consists of 16 exons and encodes 677 aminoacid residues of acid $\beta$-galactosidase, including 23 aminoacids of the signaling peptide [6]. The molecule of human acid $\beta$-galactosidase is a protein, consisting of three domains (the main catalytic TIM barell domain and $\beta 1$ and $\beta 2$-domain), which exist in the monomer form at neutral $\mathrm{pH}$ [2]. In conditions of acid $\mathrm{pH}$ of the lysosome ( $\mathrm{pH} 4-5)$ the molecule of human $\beta$-galactosidase acquires its active form by dimerization. At present 144 mutations in the gene GLBI have been described, 109 of which are missence/ nonsense mutations, 14 - deletions, 10 - insertions, 11 - mutations, causing splicing disorders [6].

Noteworthy, the differential diagnostics of GM1gangliosidosis and Morquio B disease is complicated to the common metabolic deficiency, so the final determination of the diagnosis in the patients with the deficient activity of $\beta$-galactosidase requires the molecular and genetic diagnostic methods. The identification of the primary genetic deficiency has become very relevant recently, when there are active investigations on a possible gene correction and an enzyme-replacement therapy for the patients with GM1-gangliosidosis and Morquio B disease. Also it is impossible to have prenatal diagnostics in the high risk families without the identification of the mutation, which triggered the disease.

Until today, there has been no analysis of the mutations in the gene $G L B 1$ for Ukrainian patients with GM1-gangliosidosis and Morquio B disease and their frequencies are unknown.

The aim of our work was to analyze the spectrum of mutations in the gene GLB1 in Ukrainian patients with GM1 gangliosidosis and Morquio B disease.

\section{Materials and Methods}

The analysis of mutations in the gene GLB1 was carried out in 26 patients from different regions of Ukraine in the Clinical Genetics Laboratory, NCSH OKHMATDYT, who had the preliminary diagnosis of GM1-gangliosidosis (25 patients) and Morquio B disease (1 patient), determined by the identification of the activity of acid $\beta$-galactosidase enzyme and the level of excretion for oligosaccharides and keratan sulphate with urine $[7,8]$. Genomic DNA was isolated from peripheral blood of patients using commercial kits NeoSorb (Neogene, Ukraine) according to [the] manufacturer's instructions. All 16 exons of the gene $G L B 1$, including the $5^{\prime}$ and $3^{\prime}$ untranslated regions and intron/exon boundaries, were amplified from genomic DNA using thermal cycler SimpliAmp (AB, USA). PCR primers were designed using the Primer 3 program, web-version 4.0.0 (http://bioinfo.ut.ee/primer3/) (Tab. 1).

The identification of mutations was made by the Sanger's method of direct automated sequencing using ABI Prism 3130 device (Applied Biosystems) according to the manufacturer's protocol. The analysis of sequencing results was made using programs Chromas and BLAST (http://www.ncbi.nlm. nih.gov/blast). The electronic databases of known mutations - dbSNP, 1000 Genomes, HGMD - were used to characterize the mutations. The analysis of the pathogenicity of new mutations was made using programs PolyPhen2 and Provean (http://genet- 
Table 1. Primers for sequence in the $\boldsymbol{G L B 1}$ gene.

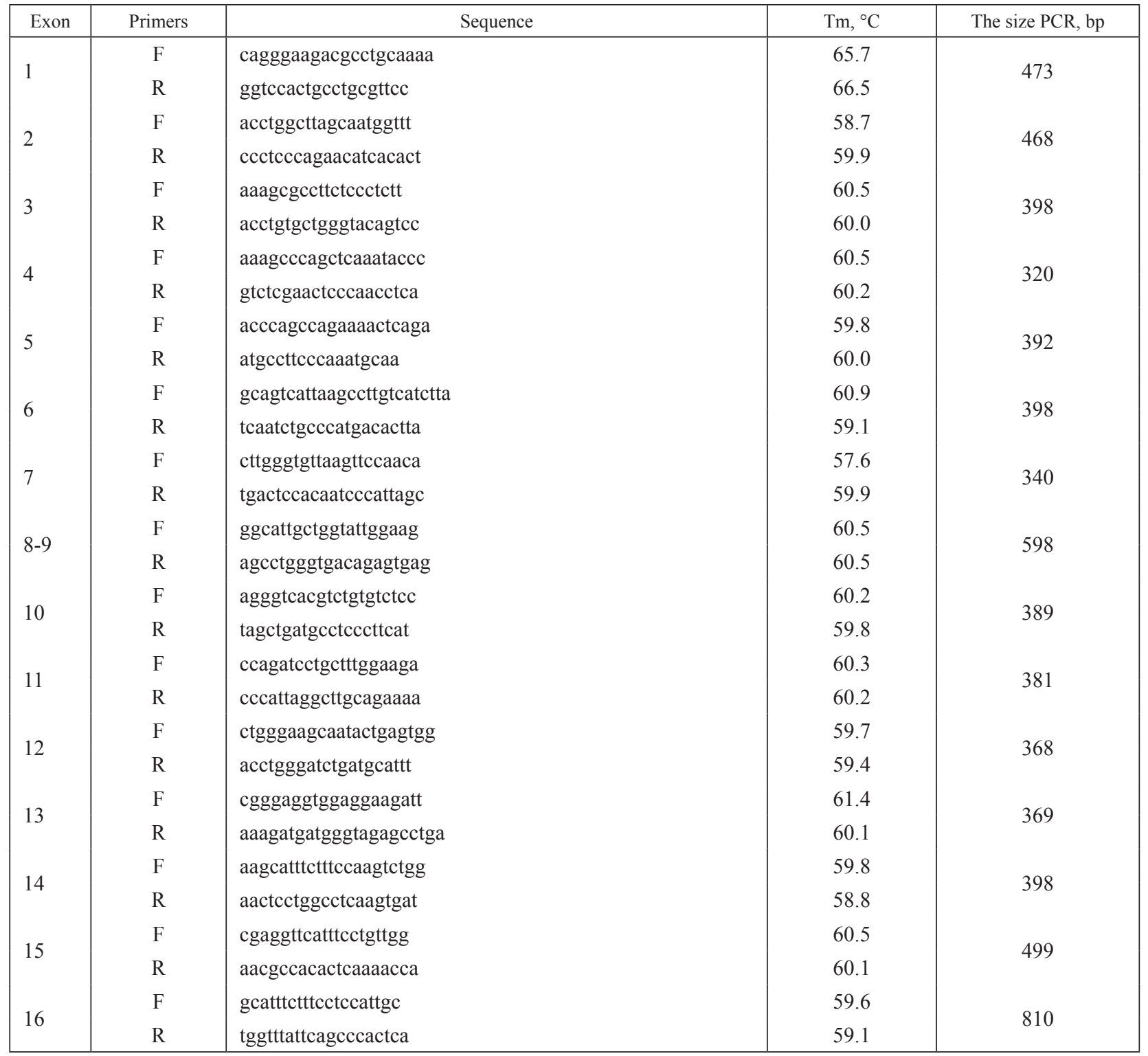

ics.bwh.harvard.edu/pph2/, http://provean.jcvi.org/ index.php).

The blood samples of 50 voluntary donors (control group) were analyzed to confirm the pathogenicity of new mutations. The voluntary donors aged 18 to 60 years without any clinical signs of lysosomal pathology gave written consent to the study. To exclude a polymorphic character of new rearrangements the RFLP analysis was used: for c.699delG - PstI digestion, for p.Gly262Ala Sau96I digestion, for c.833delG - Bmil digestion, for c.1203_1205delTTA; c.1207C > A - PseI digestion.

The parents and patients provided written consent to conduct molecular studies of blood samples of children. Committee on Bioethics allowed the study. 
New six mutations in GLB1 gene in Ukrainian patients with GM1 gangliosidosis and Morquio B disease

Table 2. The mutations in gene GLB1 in Ukrainian patients

\begin{tabular}{|c|c|c|c|c|c|}
\hline 2 & c. $176 \mathrm{G}>\mathrm{A}$ & p.Arg59His & $3 / 52$ & missence & Silva C. et al, 1999 [9] \\
\hline intron 3 & c. $397-2 \mathrm{~A}>\mathrm{G}$ & IVS4 $-2 \mathrm{~A}>\mathrm{G}$ & $1 / 52$ & splicing site & Bidchol A. M. et al, 2015 [6] \\
\hline 5 & c. $481 \mathrm{~T}>\mathrm{G}$ & p.Trp161Gly & $3 / 52$ & missence & Caciotti A. et al, 2011 [3] \\
\hline 6 & c.727G $>A$ & p.Gly243Arg & $1 / 52$ & missence & Our studies \\
\hline 7 & c. $765 \mathrm{G}>\mathrm{C}$ & p.Gln 255 His & $5 / 52$ & missence & Iwasaki H. et al, 2006 [11] \\
\hline 7 & c. $785 G>C$ & p.Gly262Ala & $1 / 52$ & missence & Our studies \\
\hline 8 & c. $808 \mathrm{~T}>\mathrm{G}$ & p.Tyr270Asp & $1 / 52$ & missence & Paschke E. et al, 2001 [12] \\
\hline 8 & c.817_818 TG $>$ CT & p.Trp273Leu & $1 / 52$ & missence & Oshima A. et al, 1991 [10] \\
\hline 12 & $\begin{array}{l}\text { p.Tyr402del; } \\
\text { p.Pro403Tre }\end{array}$ & $\begin{array}{l}\text { c.1203_1205delTTA; } \\
\text { c. } 1207 \mathrm{C}>\mathrm{A}\end{array}$ & $2 / 52$ & $\begin{array}{l}\text { deletion; } \\
\text { missence }\end{array}$ & Our studies \\
\hline intron 12 & c. $1233+8 \mathrm{~T}>\mathrm{C}$ & IVS12+8T >C & $1 / 52$ & splicing site & Our studies \\
\hline 14 & c. $1445 \mathrm{G}>\mathrm{A}$ & p.Arg482His & $1 / 52$ & missence & Oshima A. et al, 1991 [10] \\
\hline 15 & p.Glu534fs & c.1601_1602 insGCCA & $3 / 52$ & insertion & Hofer D. et al, 2009 [13] \\
\hline 16 & c. $1768 \mathrm{C}>\mathrm{T}$ & p.Arg590Cys & $1 / 52$ & missence & Boustany R. M. et al, 1993 [14] \\
\hline
\end{tabular}

\section{Results and Discussion}

While conducting the molecular analysis of the gene GLB1 in 25 Ukrainian patients with the diagnosis of GM1-gangliosidosis and 1 patient with Morquio B disease, 52 alleles were analyzed. 17 types of pathogenic mutations were identified, including 11 missence replacements, 3 deletions, 1 insertion and 2 mutations in the splicing site (Table 2).

While analyzing the frequencies of the mutations, identified by us during the molecular analysis of Ukrainian patients with GM1-gangliosidosis, it should be noted that the missence mutation $\mathrm{p}$. His281Tyr (c.841C > T) in exon 8 was the most common one. It was found in 19 out of 52 mutant alleles $(36.5 \%)$ of all the examined patients and caused the development of the infantile form of the disease. This mutation was present in 4 patients in the homozygous state and 11 patients - in the heterozygous state. The analysis of the data, published in recent 10 years regarding the distribution of the mu- tation p.His281Tyr in other populations, was conducted by us (Table 3).

The result of the analysis demonstrated that the mutation p.His281Tyr (c.841C > T) was described for single cases of patients from Germany, Italy, and Portugal, whereas no allele with this replacement was identified in other countries. This fact may testify to a considerably higher frequency of this mutation in Ukraine, compared to most countries and allows considering this mutation to be major for patients, suffering from GM1-gangliosidosis in Ukraine. The rest of mutations were observed with a smaller frequency or in single cases.

All the mutations, the prevailing majority of which, previously described in the scientific literature (Table 2), had pathogenic impact on the protein and caused the development of GM1-gangliosidosis or Morquio B disease. Most mutations (12 out of 17) were localized in exons, corresponding to TIM barell of the protein structure domain of $\beta$-galactosidase, 
Table 3. Distribution of mutations p.His281Tyr (c.841C $>$ T) in different populations.

\begin{tabular}{|l|c|c|l|}
\hline \multicolumn{1}{|c|}{ Country } & $\begin{array}{c}\text { The number of alleles with mutation } \\
\text { p.His281Tyr of the general study of alleles }\end{array}$ & $\begin{array}{c}\text { Frequency, } \\
\%\end{array}$ & \multicolumn{1}{c|}{ References } \\
\hline Ukraine & $\mathbf{1 9 / 5 2}$ & $\mathbf{3 7}$ & This work \\
Argentina & $0 / 38$ & 0 & Santamaria R. et al., 2007 [15] \\
Brazil & $0 / 130$ & 0 & Fernanda Sperb et al., 2013 [16] \\
Portugal & $2 / 28$ & 7 & Coutinho MF et al., 2012 [17] \\
Austria & $0 / 32$ & 0 & Hofer D. et al., 2010 [18] \\
Germany & $1 / 34$ & 3 & Paschke E. et al., 2001 [12] \\
Spain & $0 / 14$ & 0 & Santamaria R. et al., 2007 [19] \\
Italy & $2 / 50$ & 4 & Caciotti et al., 2011 [3] \\
UAE & $0 / 28$ & 0 & Fatma A. et al., 2013 [20] \\
Turkey & $0 / 10$ & 0 & Başak Çeltikçi et al., 2012 [21] \\
India & $0 / 100$ & 0 & Bidchol, A.M., et al., 2015 [6] \\
China & $0 / 10$ & 0 & Yang et al., 2010 [22], Hong-Lin Lei et al., 2012 [23] \\
\hline
\end{tabular}

3 more mutations - to $\beta 1$-domain and 2 mutations to $\beta 2$-domain of the protein (Fig. 1).

The electronic databases of known mutations dbSNP, 1000 Genomes, HGMD - and the published data were used to characterize the mutations and their impact on the formation of the disease phenotype. The mutations, described in the scientific literature, which promoted the formation of the early form of the disease, were found in the genotype of most patients with the infantile form of GM1gangliosidosis (Table 4).

Two mutations in two different alleles were identified in one patient with the juvenile form of GM1gangliosidosis (Table 4), one mutation is associated with the onset of the juvenile form of the disease (p.Arg201His), and another one (p.His281Tyr) is re-



Fig. 1. The localization of known and new (inside the frame) mutations, identified during our study, in exons of the gene $G L B 1$, and the scheme of the domain structure of $\beta$-galactosidase protein 
New six mutations in GLB1 gene in Ukrainian patients with GM1 gangliosidosis and Morquio B disease

Table 4. The genotype and phenotype of 26 Ukrainian patients with GM1-gangliosidosis and Morquio B disease

\begin{tabular}{|c|c|c|c|c|}
\hline Patients & $\begin{array}{l}\text { Age at the moment } \\
\text { of the visit }\end{array}$ & Phenotype & First allele & Second allele \\
\hline 1 & 12 months & Infantile form of GM1 & p.Gly243Arg & p.His281Tyr \\
\hline 2 & 8 months & Infantile form of GM1 & p.Gln255His & p.His281Tyr \\
\hline 3 & 9 months & Infantile form of GM1 & p.Gln255His & p.His281Tyr \\
\hline 4 & 10 months & Infantile form of GM1 & c.699delG & c.833delG \\
\hline 5 & 3 months & Infantile form of GM1 & IVS4 $-2 \mathrm{~A}>\mathrm{G}$ & p.His281Tyr \\
\hline 6 & 12 months & Infantile form of GM1 & c.1601_1602insGCCA & p.His281Tyr \\
\hline 7 & 12 months & Infantile form of GM1 & c.699delG & p.Arg59His \\
\hline 8 & 13 months & Infantile form of GM1 & p.His281Tyr & p.His281Tyr \\
\hline 9 & 8 months & Infantile form of GM1 & c.699delG & p.Tyr270Asp \\
\hline 10 & 14 months & Infantile form of GM1 & p.Gln 255 His & p.His281Tyr \\
\hline 11 & 12 months & Infantile form of GM1 & p.Trp161Gly & p.His281Tyr \\
\hline 12 & 14 months & Infantile form of GM1 & p.Arg59His & p.His281Tyr \\
\hline 13 & 1 month & Infantile form of GM1 & c.699delG & p.Arg59His \\
\hline 14 & 12 months & Infantile form of GM1 & p.His281Tyr & p.His281Tyr \\
\hline 15 & 10 months & Infantile form of GM1 & c.1601_1602 insGCCA & c.1601_1602 insGCCA \\
\hline 16 & 4 months & Infantile form of GM1 & p.Trp161Gly & p.Trp161Gly \\
\hline 17 & 9 months & Infantile form of GM1 & p.His281Tyr & p.His281Tyr \\
\hline 18 & 12 months & Infantile form of GM1 & c.1203_1205delTTA; c.1207C $>$ A & c.1203_1205delTTA; c.1207C $>$ A \\
\hline 19 & 14 months & Infantile form of GM1 & p.His281Tyr & p.His281Tyr \\
\hline 20 & 4 months & Infantile form of GM1 & c.699delG & c.699delG \\
\hline 21 & 7 months & Infantile form of GM1 & p.Gly262Ala & p.Arg590Cys \\
\hline 22 & 9 months & Infantile form of GM1 & p.Trp161Gly & p.Arg $482 \mathrm{His}$ \\
\hline 23 & 11 months & Infantile form of GM1 & p.Gln 255 His & p.His281Tyr \\
\hline 24 & 4 months & Infantile form GM1 & p.Gln 255 His & p.His281Tyr \\
\hline 25 & 11 y.o. & Juvenile form of GM1 & p.Arg201His & p.His281Tyr \\
\hline 26 & 7 y.o. & Morquio B disease & p.Trp273Leu & IVS12+8T $>C$ \\
\hline
\end{tabular}

the mutations, not described in the scientific literature but identified during our study, are in bold.

markable for the onset of the infantile form of GM1gangliosidosis and was found to be major for our patients. In this case the mutation p.Arg201His, which affects the development of a milder form of the disease than the mutation p.His281Tyr, had a dominating impact on the development of the patient's phenotype, which confirms the data of other authors [1].

A new mutation IVS12+8T $>\mathrm{C}$ and a known mutation p.Trp273Leu, which, according to the scientific literature, is remarkable for this syndrome and must have had the main impact on the formation of the patient's phenotype [13], were found in one patient, whose diagnosis was determined to be Morquio B using the combination of clinical signs and the results of biochemical tests. The mutation $p$.Trp273Leu has been never observed in the group of patients with GM1-gangliosidosis, examined by us, which testifies to its specific association with Morquio B disease and allows using the results of the molecular analysis for the purpose of differential diagnostics of GM1-gangliosidosis and Morquio B disease. 
Six out of 17 mutations in the gene GLBl had not been found in any electronic database (dbSNP, 1000 Genomes, HGMD) or previously described in scientific literature, including 3 deletions (c.699delG, c.833delG, c.1203_1205delTTA), 2 missence replacements (p.Gly243Arg, p.Gly262Ala) and 1 nucleotide replacement in the splicing site (IVS12+8T $>$ C) (Fig. 2). Also, none of the identified new mutations was found in the samples of 50 volunteers donors.

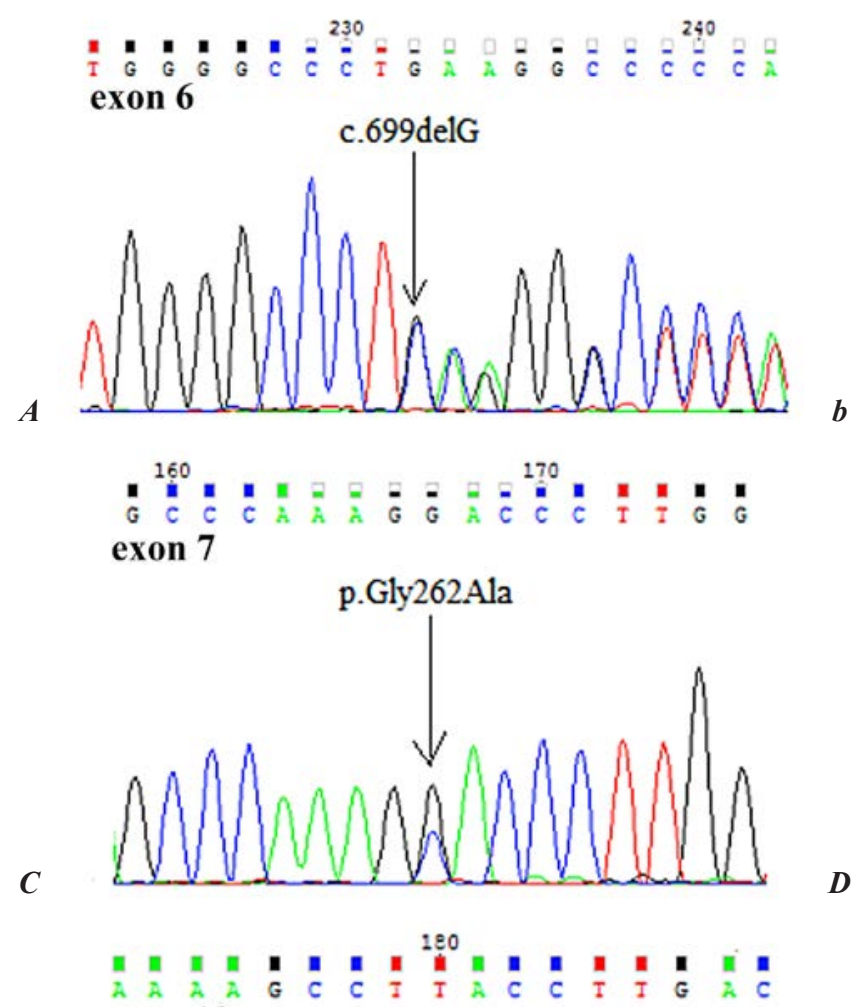

exon 12



b
The prognostic analysis of possible impact of new mutations on the structure and function of the protein of $\beta$-galactosidase was carried out using programs MutationTaster, PolyPhen 2 and Provean. The results of this study demonstrated that all new mutations were pathogenic and led to the changes in the structure and functional properties of the protein of $\beta$-galactosidase.

The newly found deletions c.699delG in exon 6 and c.833delG in exon 8 lead to the early onset of a
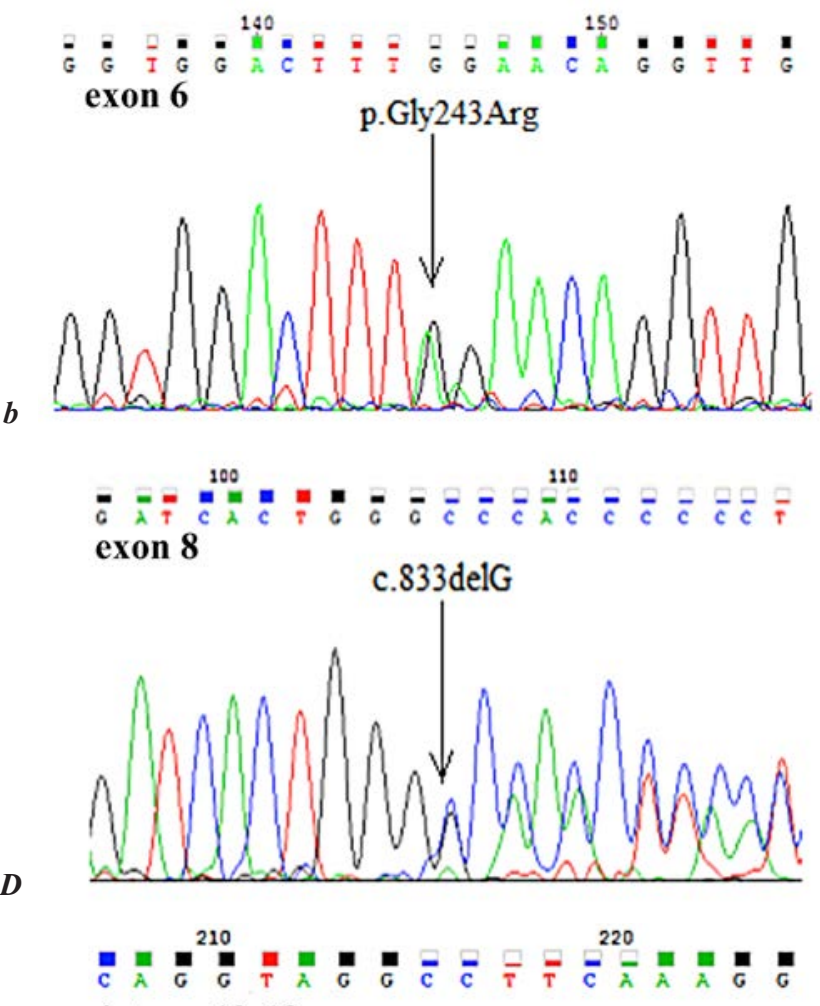

intron 12-13



Fig. 2. DNA sequences chromatogram of new mutations in the gene GLB1: $A-$ c.699delG in the heterozygous state in exon $6 ; B-$ p.Gly243Arg in the heterozygous state in exon 6; $C$ - p.Gly262Ala in the heterozygous state enkzoni $7 ; D-c .833$ delG in the heterozygous state in exon $8 ; E-$ c.1203_1205delTTA combined with p.Pro403Tre mutation in the homozygous state in exon 12; $F-$ splice site mutation IVS12 $+8 \mathrm{~T}>\mathrm{C}$ in heterozygous state in 12-13 introns. 




Fig. 3. The schematic presentation of the shortened protein of $\beta$-galactosidase due to deletions c.699delG (p.Leu233fs) $-A$ and c.833delG (p.Gly278fs) - B, which lead to premature occurrence of a stop-codon

stop-codon via 20 aminoacids and via 31 aminoacids respectively. Due to these changes the protein molecule is shorter for deletion c. $699 \mathrm{delG}$ - by $424 \mathrm{ami}-$ noacids, and for c.833delG - by 368 aminoacids, which makes its functioning impossible (Fig. 3).
The deletion c.1203_1205delTTA, identified in the homozygous state in exon 12, leads to the fallout of the aminoacid Tyr402 in $\beta 1$-domain of the protein of $\beta$-galactosidase, which has negative effect on the functional properties of the protein and may

a) p.Gly243Arg

\begin{tabular}{|c|c|c|c|c|c|c|c|c|c|c|c|c|c|c|c|c|c|c|c|c|c|c|c|c|c|}
\hline species & aa & \multicolumn{24}{|c|}{ alignment } \\
\hline Human & 243 & $\mathrm{~A}$ & $\mathrm{~L}$ & Q & G & $\mathrm{L}$ & $\mathrm{Y}$ & $\mathrm{T}$ & $\mathrm{T}$ & $\mathrm{V}$ & $\mathrm{D}$ & $\mathrm{F}$ & G & $\mathrm{T}$ & G & $\mathrm{S}$ & $\mathrm{S} \quad \mathrm{N}$ & I & $\mathrm{T}$ & $\mathrm{D}$ & A & $\mathrm{F}$ & $\mathrm{L}$ & $\mathrm{S}$ & Q \\
\hline Our patient & 243 & & & & & & & & & & D & $\mathbf{F}$ & $\mathbf{R}$ & $\mathbf{T}$ & G & $\mathbf{S}$ & S N & $\mathbf{I}$ & $\mathbf{T}$ & D & $\mathbf{A}$ & $\mathbf{F}$ & $\mathbf{L}$ & $\mathbf{S}$ & \\
\hline Mmusculus & 244 & $\mathrm{~T}$ & $\mathrm{~L}$ & Q & $\mathrm{D}$ & $\mathrm{L}$ & Y & A & $\mathrm{T}$ & $\mathrm{V}$ & $\mathrm{D}$ & $\mathrm{F}$ & G & $\mathrm{T}$ & G & $\mathrm{N}$ & $\mathrm{N} \quad \mathrm{N}$ & I & & & & & & & \\
\hline Ggallus & 236 & A & $\mathrm{L}$ & Q & G & $\mathrm{L}$ & $\mathrm{Y}$ & A & $\mathrm{T}$ & V & $\mathrm{D}$ & $\mathrm{F}$ & $\mathbf{A}$ & $\mathrm{P}$ & G & G & $\mathrm{N}$ & & & & & & & & \\
\hline Dmelanogaster & 236 & K & I & Q & G & V & $\mathrm{L}$ & A & $\mathrm{T}$ & M & $\mathrm{D}$ & $\mathrm{F}$ & G & A & $\mathrm{T}$ & $\mathrm{N}$ & $\mathrm{D}$ & $\mathrm{L}$ & $\mathrm{K}$ & $\mathrm{P}$ & & & & & \\
\hline Celegans & 254 & $\mathrm{~T}$ & $\mathrm{~V}$ & $\mathrm{E}$ & G & V & $\mathrm{F}$ & $\mathrm{P}$ & $\mathrm{T}$ & V & $\mathrm{D}$ & $\mathrm{F}$ & G PTD & $\mathrm{D}$ & A & K & $\mathrm{E}$ & I & $\mathrm{E}$ & $\mathrm{N}$ & $\mathrm{N}$ & $\mathrm{F}$ & K & $\mathrm{L}$ & \\
\hline Xtropicalis & 241 & $\mathrm{~T}$ & I & Q & G & $\mathrm{L}$ & $\mathrm{Y}$ & $\mathrm{T}$ & $\mathrm{T}$ & V & $\mathrm{D}$ & $\mathrm{F}$ & G & $\mathrm{P}$ & G & $\mathrm{S}$ & $\mathrm{N}$ & V & $\mathrm{T}$ & & & & & & \\
\hline c) p.Gly262Ala & & & & & & & & & & & & & & & & & & & & & & & & & \\
\hline Our patient & 262 & $\mathbf{A}$ & $\mathbf{F}$ & $\mathbf{L}$ & $\mathbf{S}$ & $\mathbf{Q}$ & $\mathbf{R}$ & $\mathbf{K}$ & $\mathrm{C}$ & $\mathbf{E}$ & $\mathbf{P}$ & K & $\mathbf{A}$ & $\mathbf{P}$ & $\mathbf{L}$ & I & $\mathbf{N}$ & $\mathbf{S}$ & $\mathbf{E}$ & $\mathbf{F}$ & $\mathbf{Y}$ & $\mathbf{T}$ & $\mathbf{G}$ & W & \\
\hline Ptroglodytes & 262 & A & $\mathrm{F}$ & $\mathrm{L}$ & $\mathrm{S}$ & Q & $\mathrm{R}$ & K & $\mathrm{C}$ & $\mathrm{E}$ & $\mathrm{P}$ & K & G & $\mathrm{P}$ & $\mathrm{L}$ & I & $\mathrm{N}$ & $\mathrm{S}$ & $\mathrm{E}$ & $\mathrm{F}$ & $\mathrm{Y}$ & $\mathrm{T}$ & G & W & \\
\hline Mmusculus & 263 & A & $\mathrm{F}$ & $\mathrm{L}$ & V & Q & $\mathrm{R}$ & K & $\mathrm{F}$ & $\mathrm{E}$ & $\mathrm{P}$ & K & G & $\mathrm{P}$ & $\mathrm{L}$ & I & $\mathrm{N}$ & $\mathrm{S}$ & $\mathrm{E}$ & $\mathrm{F}$ & $\mathrm{Y}$ & $\mathrm{T}$ & G & W & \\
\hline Ggallus & 255 & A & $\mathrm{F}$ & $\mathrm{L}$ & A & Q & $\mathrm{R}$ & $\mathrm{S}$ & S & E & $\mathrm{P}$ & $\mathrm{T}$ & G & $\mathrm{P}$ & $\mathrm{L}$ & $\mathrm{V}$ & $\mathrm{N}$ & $\mathrm{S}$ & $\mathrm{E}$ & $\mathrm{F}$ & $\mathrm{Y}$ & $\mathrm{T}$ & G & W & \\
\hline Trubripes & 256 & & & $\mathrm{E}$ & A & Q & $\mathrm{R}$ & $\mathrm{H}$ & A & E & $\mathrm{P}$ & $\mathrm{R}$ & G & $\mathrm{P}$ & $\mathrm{L}$ & $\mathrm{V}$ & $\mathrm{N}$ & S & $\mathrm{E}$ & F & $\mathrm{Y}$ & $\mathrm{T}$ & G & W & \\
\hline Drerio & 281 & A & $\mathrm{F}$ & $\mathrm{E}$ & A & Q & $\mathrm{R}$ & $\mathrm{H}$ & V & E & $\mathrm{P}$ & $\mathrm{R}$ & G & $\mathrm{P}$ & $\mathrm{L}$ & $\mathrm{V}$ & $\mathrm{N}$ & $\mathrm{S}$ & $\mathrm{E}$ & $\mathrm{F}$ & $\mathrm{Y}$ & $\mathrm{P}$ & G & W & \\
\hline Dmelanogaster & 253 & I & W & A & K & $\mathrm{F}$ & $\mathrm{R}$ & $\mathrm{R}$ & $\mathrm{Y}$ & Q & $\mathrm{P}$ & K & G & $\mathrm{P}$ & $\mathrm{L}$ & $\mathrm{V}$ & $\mathrm{N}$ & A & E & $\mathrm{Y}$ & $\mathrm{Y}$ & $\mathrm{P}$ & G & W & \\
\hline Celegans & 276 & & & & & & $\mathrm{R}$ & K & $\mathrm{F}$ & A & $\mathrm{P}$ & $\mathrm{N}$ & G & $\mathrm{P}$ & $\mathrm{L}$ & $\mathrm{V}$ & $\mathrm{N}$ & $\mathrm{S}$ & $\mathrm{E}$ & $\mathrm{Y}$ & $\mathrm{Y}$ & $\mathrm{P}$ & G & W & \\
\hline Xtropicalis & 260 & $\mathrm{~T}$ & $\mathrm{~F}$ & $\mathrm{~S}$ & V & Q & $\mathrm{R}$ & $\mathrm{Y}$ & $\mathrm{C}$ & E & $\mathrm{P}$ & K & $G$ & $\mathrm{P}$ & $\mathrm{L}$ & $\mathrm{V}$ & $\mathrm{N}$ & $\mathrm{S}$ & $\mathrm{E}$ & $\mathrm{F}$ & $\mathrm{Y}$ & $\mathrm{T}$ & G & W & \\
\hline
\end{tabular}

Fig. 4. The comparison of a protein sequence encoded in the gene GLB1 for a human protein and close homologs of mammals for the purpose of determining the conservative nature of aminoacid Gly in positions 243 and 262 (MutationTaster, PolyPhen2) 
lead to the change in the splicing site(MutationTaster). This deletion was found in 2 alleles in combination with the missence replacement p.Pro403Tre, which may have no considerable impact on the protein properties (MutationTaster, PolyPhen 2 and Provean).

The results of the prognostic analysis for the new missence mutations, identified by us, p.Gly243Arg (c.727G > A), p.Gly262Ala (c.785G > C), demonstrated that aminoacid Gly in both positions is rather conservative (Fig. 4), and its replacements, found in positions 243 and 262, have a damaging effect on the protein of $\beta$-galactosidase, which causes the destruction of its properties.

Another intron variant of the mutation c. $1233+8 \mathrm{~T}>\mathrm{C}(\mathrm{IVS} 12+8 \mathrm{~T}>\mathrm{C})$, found by us, was localized in the acceptor zone of the splicing site at the end of exon 12. This mutation leads to incorrect splicing of mRNA and, as a result, to the formation of abnormal protein product.

Four new mutations (c.699delG, c.833delG, Gly243Arg, p.Gly262Ala) were found in the patients with the infantile form of GM1-gangliosidosis in the heterozygous state in combination with other mutations, which, according to the data of scientific literature, cause the infantile form of this pathology (Table 3). The deletion c.699delG was also present in the genotype of one patient in the homozygous state, which resulted in very early onset of the disease. The bound inheritance of mutations c.1203_1205delTTA and p.Pro403Tre was identified in one patient in the homozygous state and conditioned the development of the infantile form of GM1-gangliosidosis. However, the mutation of the splicing site IVS12+8T $>\mathrm{C}$, found by us, was identified in the patient with Morquio B disease in the heterozygous state in combination with the missence mutation p.Trp273Leu, common for this phenotype [13].

Thus, the spectrum of mutations in the gene GLB1 in Ukrainian patients with GM1 gangliosidosis and Morquio B disease and their impact on the patients' phenotypes were studied in our work. Six new pathogenic mutations in the gene GLBI were identified with the characterization of their impact on the structure and function of the protein of $\beta$-galactosidase.
The frequencies of alleles were determined and the major nature of the mutation p.His281Tyr (c.841C > T) for Ukrainian patients with GM1-gangliosidosis was defined. These results of our study provide the necessary information for more efficient and precise molecular diagnostics of the patients with GM1gangliosidosis and Morquio B disease, for understanding the impact of mutations on the enzymatic activity which is responsible for the development of the disease. Also the results of molecular diagnostics are required to carry out prenatal diagnostics in high risk families, suffering from GM1-gangliosidosis and Morquio B disease.

\section{Conclusions}

The study of the spectrum of mutations in the gene GLB1 in 26Ukrainian patients with GM1-gangliosidosis and Morquio B disease allowed identifying 52 alleles, containing 17 types of pathogenic mutations.

The missence mutation p.His281Tyr (c.841C > T) has high incidence rate among Ukrainian patients with GM1-gangliosidosis (19/52 alleles) and may be considered to be the major mutation for this population.

The mutation p.Arg201His, which affects the development of the juvenile form of GM1gangliosidosis, has dominating impact on the development of the patient's phenotype in case of combination with more severe mutations in the genotype, which are associated with the infantile form of the disease.

The mutation p.Trp273Leu is remarkable only for the patients with Morquio B disease, which testifies to the possibility of using the results of molecular and genetic analysis during the differential diagnostics of GM1-gangliosidosis and Morquio B disease.

The study allowed identifying six new pathogenic mutations, which had not been found in any electronic databases or previously described in scientific literature, including 3 deletions (c.699delG, c.833delG, c.1203_1205delTTA), 2 missence replacements (p. Gly243Arg, p.Gly262Ala) and 1 nucleotide replacement in the splicing site (IVS12+8T $>\mathrm{C}$ ). 
The results of the molecular and genetic analysis of mutations in gene the GLB1 may be used for more precise molecular diagnostics of patients with GM1gangliosidosis and Morquio B disease and prenatal diagnostics in the high risk families, suffering from this disease.

\section{Acknowledgments}

The authors would like to express their gratitude to the doctors of the Center of Orphan Diseases and the Specialized Medical and Genetic Center, NCSH OKHMATDYT, for the provided clinical characteristics of patients.

\section{REFERENCES}

1. Johnson $W G$. Chapter 34 - $\beta$-Galactosidase Deficiency: GM1 Gangliosidosis, Morquio B Disease, and Galactosialidosis. In: Rosenberg's Molecular and Genetic Basis of Neurological and Psychiatric Disease (Fifth Edition). Academic Press. 2015; 385-94.

2. Ohto U, Usui K, Ochi T, Yuki K, Satow Y, Shimizu T. Crystal structure of human $\beta$-galactosidase: structural basis of Gm1 gangliosidosis and morquio $\mathrm{B}$ diseases. J Biol Chem. 2012;287(3):1801-12..

3. Caciotti A, Garman SC, Rivera-Colón Y, Procopio E, Catarzi S, Ferri L, Guido C, Martelli P, Parini R, Antuzzi D, Battini $R$, Sibilio $M$, Simonati A, Fontana E, Salviati A, Akinci $G$, Cereda $C$, Dionisi-Vici $C$, Deodato F, d'Amico A, d'Azzo A, Bertini E, Filocamo M, Scarpa M, di Rocco $M$, Tifft CJ, Ciani F, Gasperini S, Pasquini E, Guerrini R, Donati MA, Morrone A. GM1 gangliosidosis and Morquio B disease: an update on genetic alterations and clinical findings. Biochim Biophys Acta. 2011;1812(7):782-90.

4. Nelson J. Incidence of the mucopolysaccharidoses in Northern Ireland. Hum Genet. 1997;101(3):355-8.

5. Nelson J, Crowhurst J, Carey B, Greed L. Incidence of the mucopolysaccharidoses in Western Australia. Am J Med Genet A. 2003;123A(3):310-3.

6. Bidchol AM, Dalal A, Trivedi R, Shukla A, Nampoothiri S, Sankar VH, Danda S, Gupta N, Kabra M, Hebbar SA, Bhat RY, Matta D, Ekbote AV, Puri RD, Phadke SR, Gowrishankar K, Aggarwal S, Ranganath P, Sharda S, Kamate M, Datar CA, Bhat $K$, Kamath N, Shah H, Krishna S, Gopinath PM, Verma IC, Nagarajaram HA, Satyamoorthy K, Girisha KM. Recurrent and novel GLB1 mutations in India. Gene. 2015;567(2):173-81.

7. Mytsyk NY, Olkhovych NV, Gorovenko NG. Selective biochemical screening lysosomal storage diseases by TLC of oligosaccharides. Visnyk problem biologii i mediciny. 2016; 1(126):222-7.
8. Trofimova NS, Olkhovych NV, Gorovenko NG. Application of biochemical screening studies in early diagnostics of mucopolysaccharidosis. Visnyk problem biologii $i$ mediciny. 2015; 2(123):245-50.

9. Silva CM, Severini MH, Sopelsa A, Coelho JC, Zaha A, d'Azzo A, Giugliani R. Six novel beta-galactosidase gene mutations in Brazilian patients with GM1-gangliosidosis. Hum Mutat. 1999;13(5):401-9.

10. Oshima A, Yoshida K, Shimmoto M, Fukuhara Y, Sakuraba H, Suzuki Y. Human beta-galactosidase gene mutations in morquio B disease. Am J Hum Genet. 1991;49(5):1091-3.

11. Iwasaki H, Watanabe H, Iida M, Ogawa S, Tabe M, Higaki K, Nanba E, Suzuki Y. Fibroblast screening for chaperone therapy in beta-galactosidosis. Brain Dev. 2006;28(8):482-6.

12. Paschke E, Milos I, Kreimer-Erlacher H, Hoefler G, Beck M, Hoeltzenbein M, Kleijer W, Levade T, Michelakakis $H$, Radeva B. Mutation analyses in 17 patients with deficiency in acid beta-galactosidase: three novel point mutations and high correlation of mutation W273L with Morquio disease type B. Hum Genet. 2001;109(2):159-66.

13. Hofer D, Paul K, Fantur K, Beck M, Bürger F, Caillaud C, Fumic K, Ledvinova J, Lugowska A, Michelakakis H, Radeva B, Ramaswami U, Plecko B, Paschke E. GM1 gangliosidosis and Morquio B disease: expression analysis of missense mutations affecting the catalytic site of acid beta-galactosidase. Hum Mutat. 2009;30(8):1214-21.

14. Boustany RM, Qian WH, Suzuki K. Mutations in acid betagalactosidase cause GM1-gangliosidosis in American patients. Am J Hum Genet. 1993;53(4):881-8.

15. Santamaria $R$, Blanco $M$, Chabás A, Grinberg D, Vilageliu L. Identification of 14 novel GLB1 mutations, including five deletions, in 19 patients with GM1 gangliosidosis from South America. Clin Genet. 2007;71(3):273-9.

16. Sperb F, Vairo F, Burin M, Mayer FQ, Matte U, Giugliani R. Genotypic and phenotypic characterization of Brazilian patients with GM1 gangliosidosis. Gene. 2013;512(1):113-6.

17. Coutinho MF, Lacerda L, Macedo-Ribeiro S, Baptista E, Ribeiro H, Prata MJ, Alves S. Lysosomal multienzymatic complex-related diseases: a genetic study among Portuguese patients. Clin Genet. 2012;81(4):379-93.

18. Hofer D, Paul K, Fantur K, Beck M, Roubergue A, Vellodi A, Poorthuis BJ, Michelakakis H, Plecko B, Paschke E. Phenotype determining alleles in GM1 gangliosidosis patients bearing novel GLB1 mutations. Clin Genet. 2010; 78(3):236-46.

19. Santamaria R, Chabás A, Callahan JW, Grinberg D, Vilageliu $L$. Expression and characterization of 14 GLB1 mutant alleles found in GM1-gangliosidosis and Morquio B patients. J Lipid Res. 2007;48(10):2275-82.

20. Al-Jasmi FA, Tawfig N, Berniah A, Ali BR, Taleb M, Hertecant JL, Bastaki F, Souid AK. Prevalence and novel mutations of lysosomal storage disorders in United Arab Emirates : LSD in UAE. JIMD Rep. 2013;10:1-9. 
21. Celtikçi B, Aydın Hİ, Sivri S, Sönmez M, Topçu M, Ozkara $H A$. Four novel mutations in the $\beta$-galactosidase gene identified in infantile type of GM1 gangliosidosis. Clin Biochem. 2012;45(7-8):571-4.

22. Yang CF, Wu JY, Tsai FJ. Three novel beta-galactosidase gene mutations in Han Chinese patients with GM1 gangliosidosis are correlated with disease severity. J Biomed Sci. 2010;17:79-87.

23. Lei HL, Ye J, Qiu WJ, Zhang HW, Han LS, Wang Y, Gu XF. Beta-galactosidase deficiencies and novel GLB1 mutations in three Chinese patients with Morquio B disease or GM1 gangliosidosis. World J Pediatr. 2012;8(4):359-62.

Ідентифікація та характеристика шести нових мутацій в гені $G L B 1$ у пацієнтів 3 GM1-гангліозидозом та синдромом Моркіо В з України

Н. Й. Мицик, Н. Г. Горовенко

GM1-гангліозидоз (MIM\# 230500) та мукополісахаридоз IVB (Моркіо В, МIM\# 230500) аутосомно-рецесивні захворювання, що відносяться до лізосомних хвороб накопичення та викликані змінами в структурі одного й того ж гену- GLB1. Результатом мутацій в гені GLB1 є дефіцит кислої $\beta$-галактозидази і, як наслідок, накопичення в лізосомах пацієнтів GM1-гангліозиду та кератансульфату. Мета. Проведення аналізу спектру мутацій в гені GLB1 серед пацієнтів з GM1-гангліозидозом та синдромом Моркіо В в Україні. Результати. При проведенні молекулярного аналізу гену GLB1 у 25 українських пацієнтів 3 діагнозом GM1-гангліозидоз та у 1 пацієнта з синдромом Моркіо В було проаналізовано 52 алелі, в яких виявлено 17 типів патогенних мутацій, серед яких 11 - місенс заміни, 3 - делеції, 1 інсерція та 2 - мутації сайту слайсингу. Найчастішою виявилась місенс мутація p.His281Tyr (c.841C > T) у 8-му екзоні, яка була знайдена у 19 з 52 мутантних алелів (36,5 \%) усіх обстежених пацієнтів. В ході дослідження було виявлено шість нових мутацій, які не були знайдені в електронних базах та не були описані раніше в літературі, серед яких 3 - делеції (c.699delG, c.833delG, c.1203_1205delTTA), 2 - місенс заміни (p.Gly243Arg, p.Gly262Ala) та 1 - заміна нуклеотиду в сайті сплайсингу (IVS12+8T > C). Висновки. Результати проведеного молекулярно-генетичного аналізу мутацій в гені GLB1 можуть бути використані для більш точної молекулярної діагнос- тики хворих з GM1-гангліозидозом та синдромом Моркіо В та пренатальної діагностики в сім'ях високого ризику обтяжених даним захворюванням.

Кл юч о в і с л ов а: GM1-гангліозидо3, синдром Моркіо B, ген $G L B 1$.

\section{Идентификация и характеристика шести новых мутаций в гене $G L B 1$ у пациентов с GM1- ганглиозидозом и синдромом Моркио В с Украины}

\section{Н. Й. Мыцык, Н.Г. Горовенко}

GM1-ганглиозидоз (MIM \# 230500) и мукополисахаридоз IVB (Моркио В, MIM \# 230500) аутосомно-рецессивные заболевания, относящиеся к лизосомным болезням накопления и вызванные изменениями в структуре одного и того же гена - GLB1. Результатом мутаций в гене GLB1 является дефицит кислой $\beta$-галактозидазы и, как следствие, накопление в лизосомах пациентов GM1-ганглиозида и кератансульфата. Цель. Проведение анализа спектра мутаций в гене $G L B 1$ среди пациентов с GM1ганглиозидозом и синдромом Моркио В в Украине. Результаты. При проведении молекулярно-генетического анализа в гене GLB1 у 26 пациентов с GM1-ганглиозидозом и синдромом Моркио В в Украине было выявлено 52 аллеля, содержащих патогенные мутации. Наиболее часто встречалась миссенс мутация p.His 281Tyr (c.841C > T) в 8 экзоне, которая была найдена у 19 з 52 мутантных аллелей (36,5 \%) всех обследованных пациентов. В процесе исследования было обнаружено шесть новых патогенных мутаций, которые не были найдены в электронных базах и не описаны ранее в литературе, среди которых 3 - делеции (с.699delG, c.833delG, c.1203_1205delTTA), 2 - миссенс замены (p.Gly243Arg, p .Gly262Ala) и 1 - замена нуклеотида в сайте сплайсинга (IVS12 + 8T > C). Выводы. Результаты проведенного молекулярно-генетического анализа мутаций в гене $G L B 1$ могут быть использованы для более точной молекулярной диагностики больных с GM1-ганглиозидозом и синдромом Моркио В и пренатальной диагностики в семьях высокого риска обремененных данным заболеванием.

Кл юч е в ы е с л о в а: GM1-ганглиозидоз, синдром Моркио В, ген $G L B 1$. 